Winter 2006

\title{
Ethical Concerns for Archivists
}

Randall C. Jimerson

Western Washington University, randall.jimerson@wwu.edu

Follow this and additional works at: https://cedar.wwu.edu/history_facpubs

Part of the History Commons

\section{Recommended Citation}

Jimerson, Randall C., "Ethical Concerns for Archivists" (2006). History Faculty and Staff Publications. 15.

https://cedar.wwu.edu/history_facpubs/15

This Article is brought to you for free and open access by the History at Western CEDAR. It has been accepted for inclusion in History Faculty and Staff Publications by an authorized administrator of Western CEDAR. For more information, please contact westerncedar@wwu.edu. 


\title{
Ethical Concerns for Archivists
}

\author{
RANDALL C. JiMERSON
}

\begin{abstract}
Archivists serve many constituencies and often find themselves mediating conflicting interests among records creators, donors, researchers, and their own institutions. Ethical concerns for archivists sometimes have easy answers, but more often require sensitivity to multiple perspectives and balancing of divergent interests. The nature of the archivist's role in meeting these expectations varies somewhat according to the type of institution he or she serves. A written code of ethics can assist professional associations in evaluating actions when questions of unethical practice arise. In 1980 the Society of American Archivists adopted its first "Code of Ethics for Archivists." Revised in 1992 and again in February 2005, the code is now aspirational and general, providing a broad framework for resolving ethical dilemmas within the archival community. The basis for archival ethics consists of ten internationally accepted principles of archival ethics.
\end{abstract}

LESS THAN FOUR MONTHS after the death of Supreme Court Justice Thurgood Marshall in January 1993, reporters for The Washington Post and The New York Times used his papers at the Library of Congress to examine the positions of his fellow justices on controversial issues, such as recent disputes over abortion. Claiming to speak for "a majority of the active Justices of the Court," Chief Justice William H. Rehnquist complained on May 25 to Librarian of Congress James H. Billington, stating, “. . . we are both surprised and disappointed by the library's decision to give unrestricted public access to Justice Thurgood Marshall's papers." Rehnquist claimed that opening the papers violated "the Court's long tradition of confidentiality in its deliberations," and concluded with the threat that "future donors of judicial papers will be inclined to look elsewhere for a repository."1

1. Neil A. Lewis, "Chief Justice Assails Library on Release of Marshall Papers," New York Times, 26 May 1993.

87

The Public Historian, Vol. 28, No. 1, pp. 87-92 (Winter 2006). ISSN: 0272-3433,

electronic ISSN 1533-8576.

(C) 2006 by The Regents of the University of California and the

National Council on Public History. All rights reserved.

Please direct all requests for permission to photocopy or reproduce article content through the University of California Press's Rights and Permissions website: www.ucpress.edu/journals/rights.htm. 
Friends and family of Justice Marshall joined this controversy. William T. Coleman, Jr., a friend and personal lawyer to Marshall, argued that a clause in the Library's instrument of gift authorizing access to the papers only by "researchers or scholars engaged in serious research" should be interpreted as excluding journalists or the general public. Coleman called the release "shocking and despicable" and claimed it had caused deep dismay to Marshall's widow. Family members also contacted several Senators asking them to complain to Billington about the public release of Marshall's papers. ${ }^{2}$

This challenge to professional ethics regarding access to manuscripts and archives required responses from the library and archives professions. The American Library Association (ALA) on June 4 issued a statement wholeheartedly supporting the Library of Congress decision to comply with Justice Marshall's agreement to have his papers opened immediately after his death. "To close access to his papers when his intent that access should be open was so plain, would violate the very principles Justice Marshall himself embodied in his life's work," the ALA press release concluded. ${ }^{3}$

The Society of American Archivists (SAA) entered this controversy on June 11, 1993. SAA President Anne Kenney flew to Washington from Chicago, where she had been presiding over the SAA Council meeting, to testify before the Senate Subcommittee on Regulation and Government Information. "A primary goal of an archivist is to provide fair, equitable, and timely access to materials for researchers," Kenney testified, adding that "in relations with their donors and researchers, archivists embrace a position that supports making historical papers accessible with all due speed."4

As a member of the SAA Council, I was one of two members delegated to draft a resolution responding to the Thurgood Marshall papers controversy. We based the resolution on two policy documents previously adopted by SAA: the "Code of Ethics for Archivists" (1992), and the "ALA-SAA Joint Statement on Access to Original Research Materials" (subsequently revised). On June 13, 1993 Council adopted a revised resolution, which quoted the ALA-SAA Joint Statement in endorsing the principle of equal access to research materials without granting exclusive or privileged access. The resolution quoted the SAA "Code of Ethics," which stated that archivists "discourage unreasonable restrictions on access or use" and "observe faithfully all agreements made at the time of transfer or acquisition." The resolution concluded that "it would be a grave disservice to Justice Marshall, to scholars and other researchers, to the American people, and to the entire archival profession to ignore the will of the donor or to close or restrict access to the Thurgood Marshall Papers." SAA thus supported the Library of Congress actions, although

2. Ibid.

3. "ALA Statement on Thurgood Marshall Papers," ALAWON: ALA Washington Office Newsline, 2, no. 24 (4 June 1993).

4. "Testimony of Anne R. Kenney before Senate Subcommittee on Regulation and Government Information,” unpublished typescript, 11 June 1993. 
it added a mild rebuke, recommending that the Library's future agreements with donors should avoid ambiguous language (such as allowing only "serious research"). ${ }^{5}$

In the context of access to contemporary political papers, the Marshall case is an anomaly. Most political figures attempt to restrict or limit access to their papers and to governmental records, fearing the consequences of public disclosure. Events in recent decades have shown the power of archival records. For example, the political careers of Ferdinand Marcos of the Philippines and Kurt Waldheim of Austria disintegrated when records of their actions during World War II came to public attention. ${ }^{6}$ Likewise, Richard Nixon's secret White House tapes provided proof of his illegal actions and forced his resignation as president.

Records are powerful tools. That is one reason that the current administration has gone to extreme lengths, unprecedented since Watergate, to close governmental records from disclosure and to do "the public's business out of the public eye," as a December 2003 investigative report concluded. ${ }^{7}$ Such excessive secrecy creates ethical dilemmas for archivists, who are responsible for maintaining and providing access to records. Open access to government records is the hallmark of democratic government, essential to hold leaders accountable. Our democratic institutions depend on accurate records and public access to such information. ${ }^{8}$

The Thurgood Marshall Papers controversy illustrates some of the basic elements of archival ethics, and provides an example of how a written code of ethics can assist professional associations in evaluating actions when questions of unethical practice arise. ${ }^{9}$ Archivists must balance the sometimes conflicting rights of donors, records creators, researchers, and "third parties" affected by archival disclosure. Privacy rights of third parties, in particular, should be protected from unwarranted disclosure. Archivists must secure clear legal authority to administer materials donated or transferred to the archives or manuscript repository, whether from an individual or corporate donor. They must also adhere to the wishes of donors regarding access or restrictions on access to materials. Finally, they must provide access to materials not subject to restrictions on an equal, open, and fair basis. Except in rare cases, it is unacceptable to allow access by one category of users (e.g., academic scholars)

5. "SAA Resolution on Access to the Thurgood Marshall Papers at the Library of Congress," SAA Council, 13 June 1993.

6. Elena S. Danielson, “The Ethics of Access,” American Archivist 52 (Winter 1989): 58-59.

7. Christopher H. Schmitt and Edward T. Pound, "Keeping Secrets: The Bush Administration is Doing the Public's Business out of the Public Eye. Here's How-and Why," US News \& World Report, 22 December 2003. Available online at: http://www.usnews.com/usnews/news/articles/secrecy/22secrecy.htm (accessed 9 December 2005).

8. Randall C. Jimerson, "Secret Discussions," Letter to Editor, US News \& World Report, 26 January 2004. Available online at http:/www.usnews.com/usnews/culture/articles/040126/ 26lett.htm (accessed 9 December 2005).

9. Charles L. Miller, "Archival Ethics" (M.A. thesis, Western Washington University, July 1998), 46-53. 
but deny it to others (e.g., journalists or genealogists). Archivists should avoid the elitist notion that certain researcher groups, such as academic scholars, should be afforded special access privileges.

Archivists serve many constituencies and often find themselves mediating conflicting interests among records creators, donors, researchers, and their own institutions. Some decisions are easy. Legal rights such as copyright and open access to public records must be respected. However, other conflicts within the archives must be resolved by consideration of professional ethics. Such choices may be unclear or difficult, requiring tact, diplomacy, and balancing contradictory interests to gain a satisfactory result. Even when archivists agree on the need for equal and open access, applying the concept in complex cases is difficult. As Elena Danielson of the Hoover Institution discovered, there is often a "remarkable lack of consensus" on such decisions. ${ }^{10}$

Professional ethics for archivists in the United States have been codified only since 1980, when the Society of American Archivists (SAA) adopted its first "Code of Ethics for Archivists." This Code was revised in 1992, and again in February 2005. The previous ethics codes incorporated both guidelines for ethical conduct in the principal areas of professional activity and also a commentary to explain and provide examples of what these guidelines implied. Because this commentary provided specific applications of the general guidelines, it could "be interpreted to restrict the scope of legitimate responses."11

The new Code of Ethics represents a substantial revision. To avoid legal limitations posed by the explanatory "Commentary" of previous Codes, it omits these examples. The new Code of Ethics is thus more aspirational and general, providing a broad framework for resolving ethical dilemmas within the archival community.

In addition to the SAA Code of Ethics, archival associations in many other countries have developed guidelines for professional ethics in recent years. These codes provide a common set of ten ethical principles that enjoy worldwide acceptance. As summarized in a recent volume on archival ethics by Karen Benedict, these principles state that archivists:

1. should treat both users and colleagues fairly, without discrimination or preference;

2. must preserve the intellectual and physical integrity of their records;

3. may never alter, manipulate, or destroy data in records;

4. should discourage restricting access to records except for essential reasons of legality, privacy, or confidentiality; and must apply any such restrictions without preference or bias;

10. Danielson, 60.

11. Karen Benedict, Ethics and the Archival Profession: Introduction and Case Studies (Chicago: Society of American Archivists, 2003), 5. 
5. should protect the privacy of donors, users, and individuals who are the subject of records, and observe all legitimate access restrictions;

6. may never personally profit from privileged information in their records;

7. should use impartial judgment, rather than personal beliefs or biases, when appraising records;

8. should not publicly disparage their colleagues or other archival institutions;

9. should not personally collect manuscripts or archival records in competition with their employers; nor appraise the fiscal value of materials donated to their own institutions;

10. should use their specialized knowledge and expertise for the benefit of society. ${ }^{12}$

These ethical principles outline the archivist's obligations. Foremost among these is the responsibility to protect the integrity of records and to ensure their preservation. The archivist also has to balance responsibility to the records creators and donors, on one hand, and researchers, on the other. In addition, the archivist bears obligations to the parent institution and to the general benefit of society.

The nature of the archivist's role in meeting these expectations varies somewhat according to the type of institution he or she serves. Questions of acquisition and donor relations differ significantly between governmental archives and private archives, such as business or religious archives. Rules regarding access to archival records likewise vary dramatically between public and private archives. In the former there are usually stringent regulations providing open access to most public records, except when over-ridden by privacy or confidentiality concerns. Secrecy is antithetical to a democratic society and its governmental records. In private archives, there are few if any such requirements. Although it is desirable to make records open for public use, in order to enhance our understanding of contributions made by private organizations to society's history, private archives do not have a legal obligation to do so. When public funds are used to support activities or recordkeeping of private groups, however, access requirements may apply.

Ethical concerns for archivists sometimes have easy answers, but more often require sensitivity to multiple perspectives and balancing of divergent interests. The policies and interests of the larger institution which the archives serves also have to be taken into account. At times the institution's needs will dictate actions that donors, researchers, or other parties might find unsatisfactory. Above all, however, archivists and those responsible for manuscripts and archival collections should remember their professional obligations to behave ethically in their dealings with all parties. A professional archivist is an ethical archivist. 
The Thurgood Marshall Papers case reminds us that access to records can have important political consequences. The archivist plays an important role in mediating conflicting interests of researchers, donors, and third parties. This is not a passive or neutral position. However, paying close attention to professional ethics can prepare archivists to be "uniquely qualified to balance competing demands for open access and for protection of confidential information."13 This is a responsibility of profound professional significance. It requires a clear understanding of archival ethics.

Randall C. Jimerson is professor of history and director of the Graduate Program in Archives and Records Management at Western Washington University in Bellingham, Washington. He is a fellow and past president of the Society of American Archivists. He is currently president of the Mount Vernon (WA) chapter of ARMA, and is a former president of New England Archivists, which presented him the Distinguished Service Award in 1994. He is editor of American Archival Studies: Readings in Theory and Practice (SAA, 2000), and author of The Private Civil War: Popular Thought During the Sectional Conflict (LSU Press, 1988). His current research includes a broad study of the importance of documents and archives in American history from 1791 to 1940, and an examination of the civil rights movement in Alabama. He received the Ph.D. in American History at the University of Michigan, and worked as an archivist at the Bentley Historical Library and at Yale University. From 1979 to 1994 he was university archivist and director of the Historical Manuscripts and Archives Department of the University of Connecticut Libraries, where he also led the graduate program in History and Archival Management.

13. "Nixon Papers Controversy," Society of American Archivists Newsletter, July 1986, in Danielson, 59. 